\title{
Natural volcanic pozzolan-and granulated blast furnace slag-based alkali-activated repair mortar
}

\author{
Rafael Robayo-Salazar ${ }^{1}$, Carlos Jesus ${ }^{2}$, Ruby Mejía de Gutiérrez ${ }^{1}$ and Fernando Pacheco-Torgal ${ }^{2}$ \\ ${ }^{1}$ Universidad del Valle, Cali, Colombia \\ ${ }^{2}$ Universidade do Minho, Guimarães, Portugal \\ Email: rafael.robayo, ruby.mejia \{@correounivalle.edu.co\}, \{cjesus, torgal\}@civil.uminho.pt
}

\begin{abstract}
An alkali-activated binary mortar (AABM) was studied as a possible alternative to traditional surface protection systems (coatings) or repair materials. A natural volcanic pozzolan $(\mathbf{7 0 \%})$ and a granulated blast furnace slag $(30 \%)$ were employed as precursors. According to standard specifications (EN 1504-3) and the properties of $\mathrm{AABM}$ the material was classified as a class $\mathrm{R} 2$-repair mortar.
\end{abstract}

Index Terms- natural volcanic pozzolan, alkali-activated mortar, coating mortar, repair mortar

\section{INTRODUCTION}

Alkali-activated cements (AAC) are binders that result from the chemical interaction between strongly alkaline solutions (activator) and silicoaluminate (precursor), with low and high calcium contents, which may be of natural origin, such as natural clays or pozzolans, or of artificial origin, such as industrial waste and by-products. At relatively low processing temperatures $\left(25-100^{\circ} \mathrm{C}\right)$, this chemical interaction between the alkaline activator and the precursor promotes the formation, subsequent coagulation and precipitation of reaction products, which ultimately define the excellent mechanical and durable properties of this type of material [1-5]. Recently, AAC have undergone extensive development and have gradually attracted the attention of the scientific and industrial world. They are considered materials of high potential, partly due to their technical and environmental advantages, their versatility and the ease of implementing new technologies into their production, which enables their application in various engineering fields, such repair and surface protection of concrete structures.

The European EN 1504 standard [6] specifies the requirements for the classification of products and systems that will be employed for the structural and nonstructural protection or repair of reinforced concrete. Part 3 of this standard addresses repair mortars and concretes that can be used in conjunction with other products and systems to restore and/or replace defective or contaminated concrete and protect the reinforcement to extend the service life of a concrete structure that has

Footnotes: 8-point Times New Roman font;

Manuscript received July 1, 2012; revised August 1, 2012; accepted September 1, 2012.

Copyright credit, project number, corresponding author, etc. deteriorated. The EN 1504-3 defines four classes of repair products (structural (class R3 and class R4) and nonstructural (class R1 and class R2)) based on the physicomechanical characteristics and their level of adherence (pull-off) to the substrate (table 1).

TABLE 1. MAIN CHARACTERISTICS AND/OR REQUIREMENTS OF THE REPAIR PRODUCTS (STRUCTURAL AND NONSTRUCTURAL) ACCORDING TO THE EN 1504-3 STANDARD [6].

\begin{tabular}{|c|c|c|c|c|}
\hline \multirow{2}{*}{ Characteristic } & \multicolumn{4}{|c|}{ Requirements } \\
\cline { 2 - 5 } & \multicolumn{2}{|c|}{ Structural } & \multicolumn{2}{c|}{ Non-structural } \\
\cline { 2 - 5 } & $\begin{array}{c}\text { Class } \\
\mathrm{R} 4\end{array}$ & $\begin{array}{c}\text { Class } \\
\mathrm{R} 3\end{array}$ & $\begin{array}{c}\text { Class } \\
\mathrm{R} 2\end{array}$ & Class R1 \\
\hline $\begin{array}{c}\text { Compressive } \\
\text { strength }\end{array}$ & $\geq 45$ & $\geq 25$ & $\geq 15$ & $\geq 10 \mathrm{MPa}$ \\
\hline $\begin{array}{c}\text { Adherence (pull- } \\
\text { off) }\end{array}$ & $\geq 2$ & $\geq 1.5$ & $\geq 0.8$ & $\geq 0.5 \mathrm{MPa}$ \\
\hline $\begin{array}{c}\text { Modulus of } \\
\text { elasticity }\end{array}$ & $\mathrm{MPa}$ & $\mathrm{MPa}$ & $\mathrm{MPa}$ & No requirement \\
\hline $\begin{array}{c}\text { Capillary } \\
\text { absorption }\end{array}$ & \multicolumn{5}{|c|}{$\leq 0.5 \mathrm{~kg} / \mathrm{m}^{2} \cdot \mathrm{h}^{0.5}$} & $\begin{array}{c}\text { No } \\
\text { requirement }\end{array}$ \\
\hline
\end{tabular}

This study evaluate an alkali-activated mortar (AABM) based on a natural volcanic pozzolan as a protection or repair material according to the EN 1504-3 standard [6].

\section{MATERIALS AND METHODOLOGY}

\section{A. Materials}

A binary mixture composed of a natural volcanic pozzolan (NP) $(70 \%)$ and granulated blast furnace slag (GBFS) (30\%) was used as precursor of the alkaliactivated mortar. The chemical compositions of these materials are listed in Table 2. A solution with $\mathrm{NaOH}$ and $\mathrm{Na}_{2} \mathrm{SiO}_{3}$ (waterglass; $\mathrm{SiO}_{2}=58.7 \%, \mathrm{Na}_{2} \mathrm{O}=13.5 \%, \mathrm{H}_{2} \mathrm{O}$ $=45.2 \%$ ) was employed as activator.

TABLE 2. CHEMICAL COMPOSITION OF THE NP AND GBFS USED AS PRECURSORS (WT \% OF OXIDES).

\begin{tabular}{|c|c|c|}
\hline Oxide & NP & GBFS \\
\hline $\mathrm{SiO}_{2}$ & 61.99 & 37.74 \\
\hline $\mathrm{Al}_{2} \mathrm{O}_{3}$ & 15.52 & 15.69 \\
\hline $\mathrm{Fe}_{2} \mathrm{O}_{3}$ & 7.33 & 1.85 \\
\hline $\mathrm{CaO}$ & 5.19 & 40.30 \\
\hline $\mathrm{Na}_{2} \mathrm{O}$ & 4.07 & 0.20 \\
\hline $\mathrm{MgO}$ & 2.49 & 1.30 \\
\hline $\mathrm{K}_{2} \mathrm{O}$ & 1.59 & 0.40 \\
\hline LOI* & 0.48 & --- \\
\hline Others & 1.34 & 2.52 \\
\hline
\end{tabular}


The concrete used as substrate was prepared with CEM I 42.5 R.

\section{B. Mixtures design and experimental tests}

The dosage per cubic metre of the AABM is listed in Table 3. The liquid/solids ratio (L/S) for AABM was 0.35. The mixtures were obtained in a Controls L5 automatic mixer with a total mixing time of 5 min. After $24 \mathrm{hrs}$, the specimens were demoulded and cured in laboratory conditions (temperature: $20 \pm 3^{\circ} \mathrm{C}$ and relative humidity: $70 \pm 10 \%$ ).

TABLE 3. DOSAGE (KG) PER CUBIC METRE $\left(\mathrm{M}^{3}\right)$ OF ALKALI ACTIVATED BINARY MORTAR (AABM) (COATING MORTAR).

\begin{tabular}{|c|c|c|c|c|c|c|}
\hline Material & NP & GBFS & Water & $\mathrm{NaOH}$ & $\mathrm{Na}_{2} \mathrm{SiO}_{3}$ & Sand \\
\hline $\mathrm{kg} / \mathrm{m}^{3}$ & 363.0 & 155.6 & 138.4 & 36.5 & 172.6 & 1426.0 \\
\hline
\end{tabular}

To evaluate the effect of the substrate quality on the adherence (pull-off) of the AABM, three types of OPC concretes (substrates) were obtained. The proportioning of these concretes was based on obtaining three strength classes (EN 206-1): C25/30, C35/45 and C50/60.

The compressive strength was obtained in a LLOYD LR50K universal press by testing $50.8 \mathrm{~mm}$ cube specimens for AABM (ASTM C109). The determination of the secant elastic modulus in compression (EN 1239013) of the AABM (28 days) was performed using cylinders with a diameter of $60 \mathrm{~mm}$. The three-point flexural strength (ASTM C348) of the AABM (28 days) was obtained in $40 \mathrm{~mm} \times 40 \mathrm{~mm} \times 160 \mathrm{~mm}$ beams. The splitting tensile strength of the AABM was evaluated at 28 days in cylinders with a diameter of $60 \mathrm{~mm}$ by adapting the procedure described in the ASTM C496 standard.

The water absorption coefficient (capillarity) of the AABM was determined at 28 days of curing based on the EN 1015-18 standard. For the measurement of the shrinkage, $40 \mathrm{~mm}$ x $40 \mathrm{~mm} \times 160 \mathrm{~mm}$ beams were used. The procedure for the evaluation of the length change followed the recommendations of the ASTM C490 standard. For this test, the measurements were recorded once the beams hardened and could be demoulded $(\approx 2 \mathrm{hrs}$ for the AABM and $24 \mathrm{hrs}$ for the reference material (OPC substrate) and continued until 28 days of curing. The specimens were kept in laboratory conditions $\left(20 \pm 3{ }^{\circ} \mathrm{C}\right.$ and $70 \pm 10 \%$ of relative humidity) during the entire test. To record the length change, a Mahr-MarCator 1075R digital device was employed.

The pull-off test was performed following the recommendations of the EN 1542 standard [7]. The substrates and coating mortar (AABM) for pull-off test were prepared and applied according to the procedure established by this standard. The coating thickness for pull-off test was $20 \mathrm{~mm}$.

The values reported in each of the physicomechanical tests correspond to an average of three specimens per mixture and/or test age.

\section{RESULTS AND DISCUSSION}

Figure 1 presents the compressive strength evolution of the alkaline mortar (AABM) with respect to the minimum values established for commercial cements (UG type) by the ASTM C1157 standard; $13 \mathrm{MPa}$ to three days of curing, $20 \mathrm{MPa}$ to seven days of curing and $28 \mathrm{MPa}$ to 28 days of curing. This comparison enabled classification of the alkaline binder based on the mechanical performance of the AABM (34.8 MPa at 28 days) as GU (general use) type cement. The rapid development of compressive strength of the AABM (10.8 $\mathrm{MPa}$ to 1 day) is an advantage in the field of "fast repair materials", commonly used in "patch repair" applications that require almost instantaneous adherence to the substrate.

The compressive strength of the repair product is an important parameter in applications in which load transfer through the repaired area must be considered. According to the minimum compressive strength requirements (28 days) established by the EN 1504-3 standard (Table 1) for the classification of repair products, the AABM can be classified as a "structural repair mortar, class R3", and attain a value of $34.8 \mathrm{MPa}(>25 \mathrm{MPa})$ (Figure 1). However, the compressive strength is not the only parameter demanded by this classification (Table 1).

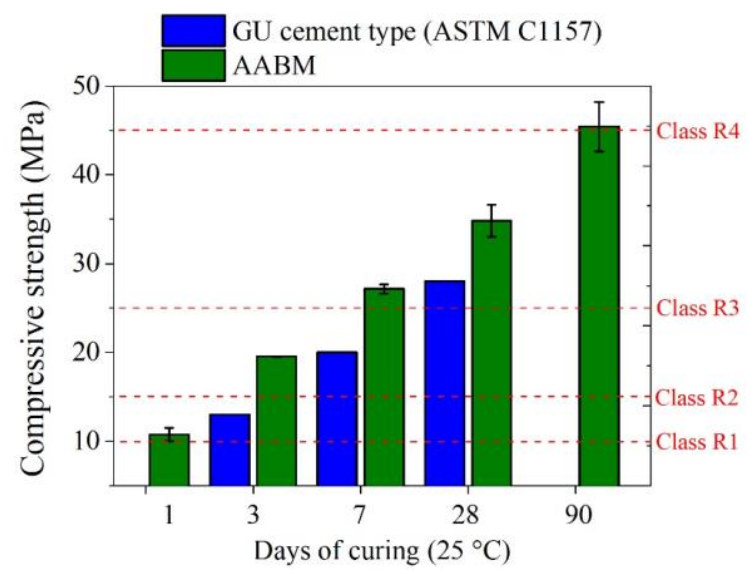

Figure 1. Compressive strength evolution of the AABM (cured at 25 $\left.{ }^{\circ} \mathrm{C}\right)$

Based on previous considerations, some applications (non-structural) do not require an elevated compressive strength by the repair material. However, a direct relationship exists between the mechanical properties and the adherence to the substrate (OPC concrete) [8], which must be a minimum of $0.8 \mathrm{MPa}$ according to the EN 1504-3 standard. A tensile strength of the repair material that is greater than the tensile strength of the substrate favours a "pull-off" failure in the interior of the substrate (ideal situation). Conversely, a tensile strength of the repair material that is less than the tensile strength of the substrate would provoke the cohesive failure of the coating if its adherence to the substrate exceeds its tensile strength. In this case, the EN 1504-3 standard demands a minimum tensile strength of the repair material of 0.5 $\mathrm{MPa}$. Table 4 lists the results obtained for the splitting tensile strength $(2.13 \mathrm{MPa})$ and flexural strength $(3.75$ 
$\mathrm{MPa}$ ) of the AABM, determined at 28 days of curing. These values are consistent with the compressive strength level (Figure 1) attained by the AABM and exceed the value specified by the EN 1504-3 standard.

The AABM attained a modulus of elasticity value of 8.66 GPa at 28 days of curing (Table 4), which coincides with the range $(3.8-15 \mathrm{GPa})$ reported by Kheradmand et al. in 2017 [9] for alkaline mortars. These authors claim that an adjustment in the alkaline activator content, that is, a reduction of the activator/binder ratio at the same time of an increment in the $\mathrm{Na}_{2} \mathrm{SiO}_{3} / \mathrm{NaOH}$ ratio causes higher modulus of elasticity values; however, these adjustments also increase the shrinkage level and the cracking susceptibility of the alkaline mortars [10-12].

TABLE 4. COMPLEMENTARY MECHANICAL PROPERTIES OF THE AABM (28 DAYS OF CURING AT $\left.25^{\circ} \mathrm{C}\right)$.

\begin{tabular}{|c|c|c|}
\hline $\begin{array}{c}\text { Splitting tensile strength } \\
(\mathrm{MPa})\end{array}$ & $\begin{array}{c}\text { Flexural } \\
\text { strength } \\
(\mathrm{MPa})\end{array}$ & $\begin{array}{c}\text { Modulus of elasticity } \\
(\mathrm{GPa})\end{array}$ \\
\hline $2.13 \pm 0.08$ & $3.75 \pm 0.47$ & $8.66 \pm 0.25$ \\
\hline
\end{tabular}

Incompatibilities between the repair mortar and the surface to be repaired can cause premature failure, especially due to the differential shrinkage level [12,13]. Figure 2 shows the shrinkage percentage (-), recorded up to 28 days, of the AABM with respect to the OPC substrate $(-0.37 \%$ vs. $-0.08 \%$, respectively). Even with this shrinkage level (high), note than the coating did not present signs of surface cracking (cracks). According to Kani and Allahverdi (2011) [10], a decrease in the concentration is possible with a decrease in the $\mathrm{SiO}_{2} / \mathrm{Na}_{2} \mathrm{O}, \mathrm{H}_{2} \mathrm{O} / \mathrm{Al}_{2} \mathrm{O}_{3}$ and/or $\mathrm{Na}_{2} \mathrm{O} / \mathrm{Al}_{2} \mathrm{O}_{3}$ molar ratios; however, some authors [14-18] have demonstrated that these adjustments affect the mechanical performance and adherence (pull-off) to the substrate.

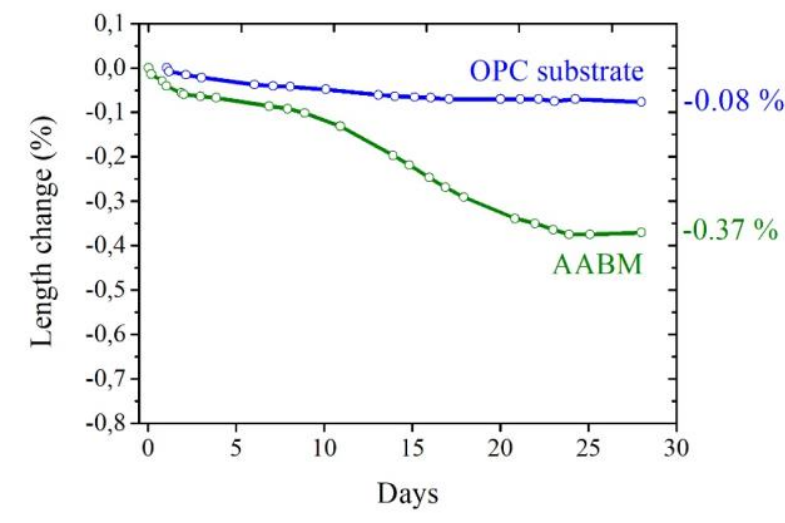

Figure 2. Shrinkage level (ASTM C490) of AABM vs OPC substrate.

In addition to the required mechanical specifications, the exposure conditions to which the material will be subjected are considered important, as these conditions determine the durability of the system. For this reason, the EN 1504-3 standard specifies a capillary absorption coefficient that is less than $0.5 \mathrm{~kg} / \mathrm{m}^{2} \cdot \mathrm{h}^{0.5}$ as an acceptable limit of the permeability level for "class $R 2, R 3$ and $R 4$ " repair products. For the case of "class $R I$ ", no value is specified. According to the results (Figure 3), the AABM presents a capillary absorption coefficient of 0.5088 $\mathrm{kg} / \mathrm{m}^{2} \cdot \mathrm{h}^{0.5}$, which can be considered as the limit for complying with the specification established by the standard.

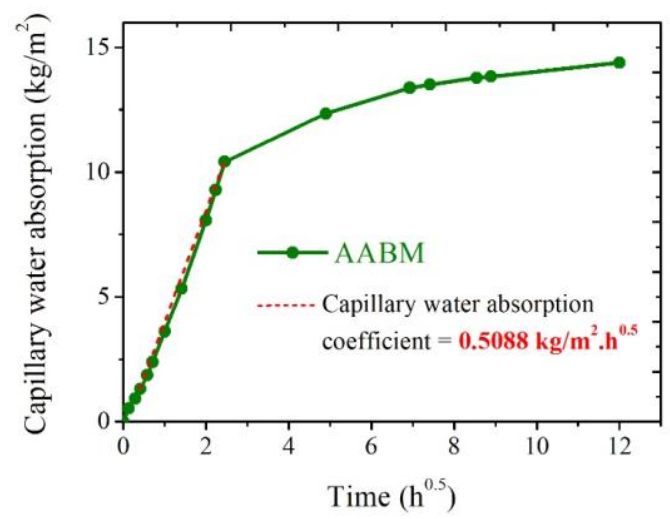

Figure 3. Capillary water absorption (EN 1015-18) of the AABM.

Figure 4 shows the results of the pull-off test as a function of the class of substrate (C25/30, C35/45 and C50/60). According to the specifications of the EN 15043 standard, the adherence of the repair material to the substrate must exceed 1.5 MPa and 2.0 MPa for "class $R 3$ " and "class $R 4$ " structural products, respectively, and exceed $0.8 \mathrm{MPa}$ for "class R1" and "class R2" nonstructural products (Table 1). The AABM adherence was $0.75 \mathrm{MPa}, 1.14 \mathrm{MPa}$ and $1.24 \mathrm{MPa}$ for the case of $\mathrm{C} 25 / 30, \mathrm{C} 35 / 45$ and $\mathrm{C} 50 / 60$, respectively. This finding indicates that the AABM can be classified as a "class R2" repair mortar, with its adherence improved by the quality of the substrate. Bonaldo et al., 2005 [19] report similar adherence results for OPC concretes using this method (pull-off) and highlight that the strength class of the substrate is related to the porosity of the surface that is in contact with the coating (interface). The lower the substrate strength is, the higher the surface porosity and the tendency towards water absorption, which promotes the formation of a water film during the coating application and affects its adherence.

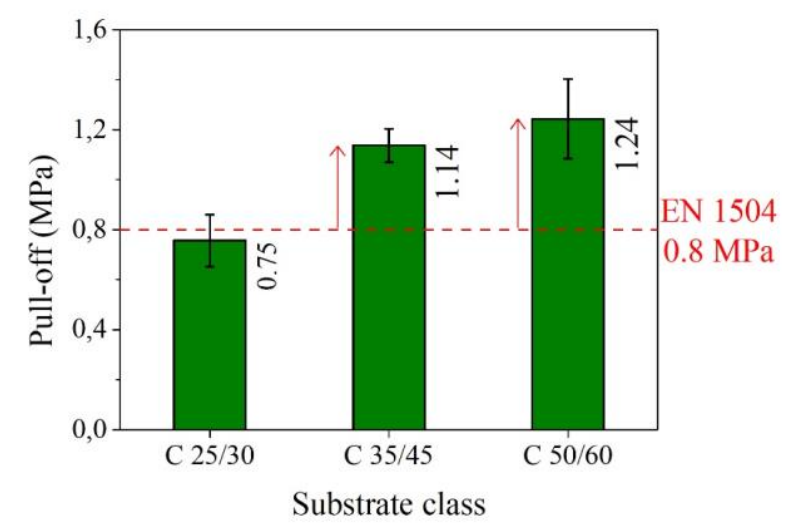

Figure 4. AABM adherence (pull-off) as a function of substrate class (C25/30, C35/45 and C50/60).

According to the EN 1542 standard [7] classification presented in Table 5, the pull-off failure of the AABM for the three classes of substrate (C25/30, C35/45 and 
C50/60) corresponds to the combination of an A/B-type adhesive failure and a B-type cohesive failure (Figure 5). Given the absence of B/C-type failures, the cohesive rupture of the coating is discarded, which indicates that the tensile strength of the AABM (2.13 MPa) was not exceeded by the maximum load during the pull-off test $(0.75-1.24 \mathrm{MPa})$. The strength of the OPC substrates, although they favoured the adherence, did not influence the type of failure as the force did not exceed the tensile strength of the OPC substrates in any of the cases.

TABLE 5. TYPE OF FAILURE CLASSIFICATION AFTER THE PULL-OFF TEST (EN 1542) [7].

\begin{tabular}{|c|c|}
\hline $\begin{array}{c}\text { Type of } \\
\text { failure }\end{array}$ & Descriptions \\
\hline $\mathrm{A}$ & Cohesion failure in the concrete substrate (ideal) \\
\hline $\mathrm{A} / \mathrm{B}$ & $\begin{array}{c}\text { Adhesion failure between the substrate and the first } \\
\text { layer (ideal) }\end{array}$ \\
\hline $\mathrm{B}$ & Cohesion failure in the first layer \\
\hline $\mathrm{B} / \mathrm{C}$ & Adhesion failure between the first and second layer \\
\hline $\mathrm{C}$ & Cohesion failure in the second layer \\
\hline$-/ \mathrm{Y}$ & $\begin{array}{c}\text { Adhesion failure between the last layer and adhesive } \\
\text { layer (abnormal) }\end{array}$ \\
\hline $\mathrm{Y}$ & Cohesion failure in the adhesive layer (abnormal) \\
\hline $\mathrm{Y} / \mathrm{Z}$ & $\begin{array}{c}\text { Adhesion failure between the adhesive layer and the } \\
\text { dolly (abnormal) }\end{array}$ \\
\hline
\end{tabular}

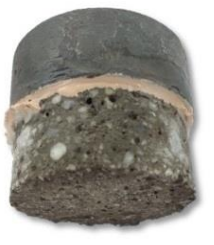

C 25/30

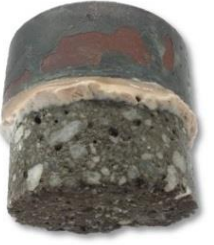

C $35 / 45$

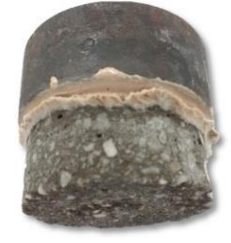

C 50/60
Figure 5. Visual determination of the type of failure (pull-off test).

\section{CONCLUSIONS}

According to the characterisation of the AABM and the specification of the EN 1504-3 standard regarding compressive strength, splitting tensile strength, adherence (pull-off), modulus of elasticity and capillary absorption, this material can be classified as a "non-structural repair mortar, class R2", which is suitable for use in the repair of structures that do not have to transfer loads through the repaired area.

Additional aspects of this classification, which are associated with the use of this material as a repair or surface protection (coating) system to promote a high durability (or chemical resistance) in concrete structures subjected to severe conditions $\left(\mathrm{CO}_{2}\right.$, chloride, sulphates, acids, fire, etc.), are considered of interest for subsequent studies.

\section{ACKNOWLEDGMENT}

R. Robayo-Salazar appreciates the support of COLCIENCIAS regarding the training of doctors in Colombia (call No. 617 of 2013) and the "Centre for Territory, Environment and Construction" ("Centro de Território, Ambiente e Construção”) (CTAC) of the University of Minho (Universidade do Minho)
(Guimarães, Portugal) for their support of the development of some of the experimental tests.

\section{REFERENCES}

[1] V.D. Glukhovsky, G.. Rostovskaja, G.V. Rumyna, High strength slag-alkaline cements, in: 7th Int. Congr. Chem. Cem. Vol. 3, 1980: pp. 164-168.

[2] J. Davidovits, Properties of Geopolymer Cements, First Int. Conf. Alkaline Cem. Concr. (1994) 131-149.

[3] C. Shi, M. Tang, X. Wu, Research on alkali-activated cementitious systems in China: a review, Adv. Cem. Res. 5 (1993) 1-7. doi:10.1680/adcr.1993.5.17.1.

[4] F. Puertas, Cementos de escorias activadas alcalinamente: Situación actual y perspectivas de futuro, Mater. Construcción. 45 (1995) 53-64. doi:10.3989/mc.1995.v45.i239.553.

[5] J.L. Provis, J.S.J. van Deventer, Geopolymers: Structures, Processing, Properties and Industrial Applications, 2009. doi: $10.1533 / 9781845696382$.

[6] European Standard, EN 1504. Products and systems for the protection and repair of concrete structures. Part 3: Structural and non-structural repair, (2005).

[7] European Standard, EN 1542. Products and systems for the protection and repair of concrete structures - Test methods Measurement of bond strength by pull-off, (1999).

[8] G. Fahim Huseien, J. Mirza, M. Ismail, S.K. Ghoshal, A Abdulameer Hussein, Geopolymer mortars as sustainable repair material: A comprehensive review, Renew. Sustain. Energy Rev. 80 (2017) 54-74. doi:10.1016/j.rser.2017.05.076.

[9] M. Kheradmand, Z. Abdollahnejad, F. Pacheco-Torgal, Shrinkage performance of fly ash alkali-activated cement based binder mortars, KSCE J. Civ. Eng. 00 (2017) 1-11. doi:10.1007/s12205-017-1714-3.

[10] E.N. Kani, A. Allahverdi, Investigating shrinkage changes of natural pozzolan based geopolymer cement paste, Iran. J. Mater. Sci. Eng. 8 (2011) 50-60.

[11] Z. Zhang, X. Yao, H. Wang, Potential application of geopolymers as protection coatings for marine concrete: III. Field experiment, Appl. Clay Sci. 67-68 (2012) 57-60. doi:10.1016/j.clay.2012.05.008.

[12] E. Vasconcelos, S. Fernandes, J.L. Barroso Aguiar, F. PachecoTorgal, Concrete retrofitting using metakaolin geopolymer mortars and CFRP, Constr. Build. Mater. 25 (2011) 3213-3221. doi:10.1016/j.conbuildmat.2011.03.006.

[13] D. Cusson, Durability of repaired concrete structures, in: Fail. Distress Repair Concr. Struct., 2009: pp. 296-321. doi:10.1533/9781845697037.2.296.

[14] S. Kramar, A. Šajna, V. Ducman, Assessment of alkali activated mortars based on different precursors with regard to their suitability for concrete repair, Constr. Build. Mater. 124 (2016) 937-944. doi:10.1016/j.conbuildmat.2016.08.018.

[15] M. Irfan Khan, K. Azizi, S. Sufian, Z. Man, Effect of Na/Al and $\mathrm{Si} / \mathrm{Al}$ Ratios on Adhesion Strength of Geopolymers as Coating Material, Appl. Mech. Mater. 625 (2014) 85-89. doi:10.4028/www.scientific.net/AMM.625.85.

[16] T. Phoo-ngernkham, V. Sata, S. Hanjitsuwan, C. Ridtirud, Shigemitsu Hatanaka, Prinya Chindaprasirt, High calcium fly ash geopolymer mortar containing Portland cement for use as repair material, Constr. Build. Mater. 98 (2015) 482-488. doi:http://dx.doi.org/10.1016/j.conbuildmat.2015.08.139.

[17] T. Phoo-ngernkham, A. Maegawa, N. Mishima, S. Hatanaka, P. Chindaprasirt, Effects of sodium hydroxide and sodium silicate solutions on compressive and shear bond strengths of FA - GBFS geopolymer, Constr. Build. Mater. 91 (2015) 1-8. doi:10.1016/j.conbuildmat.2015.05.001.

[18] H.Y. Zhang, V. Kodur, S.L. Qi, B. Wu, Characterizing the bond strength of geopolymers at ambient and elevated temperatures, Cem. Concr. Compos. 58 (2015) 40-49. doi:10.1016/j.cemconcomp.2015.01.006.

[19] E. Bonaldo, J.A.O. Barros, P.B. Lourenço, Bond characterization between concrete substrate and repairing SFRC using pull-off testing, Int. J. Adhes. Adhes. 25 (2005) 463-474. doi:10.1016/j.ijadhadh.2005.01.002. 


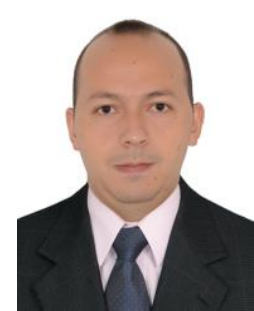

Rafael Robayo-Salazar is Materials Engineer, $\mathrm{PhD}$ Candidate at the Engineer Faculty of the Universidad del Valle (CaliColombia) and researcher in the Composites Materials Group (GMC) of the School of

Materials Engineering. His major research interests are eco-materials, eco-efficient construction and building materials, alkaliactivated materials, construction and demolition wastes, concrete durability, industrial waste recycling, composites materials, fiberreinforced concretes and concrete technology-in general.
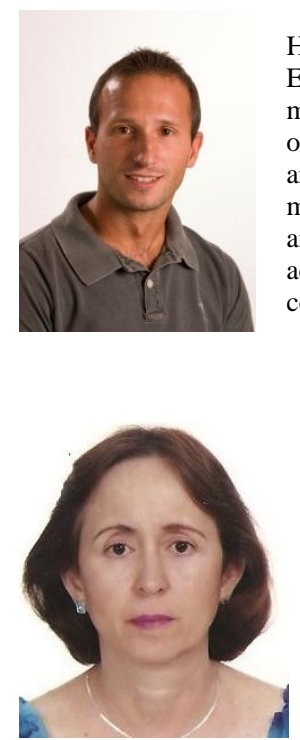

Carlos Jesus is MSc. in Civil Engineer Higher Technician at School of Civil Engineering of University of Minho and member at C-TAC Research Centre, University of Minho, Portugal. His major research interests are eco-efficient construction and building materials, mechanical properties, construction and demolition wastes, geopolymers, alkaliactivated cement-based binders (AACB), concrete durability and civil engineering.

Ruby Mejía de Gutiérrez is $\mathrm{PhD}$, Titular Professor at School of Materials Engineering of Universidad del Valle (Cali, Colombia) and leader of the Composites Materials Research Group (GMC). Her projects and research work have given rise to 4 national patents and an appreciable number of international papers $(>200)$. She has directed and contributed to the training of an appreciable number of professionals at the undergraduate, masters and doctorate level. She is reviewer for several international journals. Her major research interests are alkali-activated materials, geopolymers, concrete durability, industrial waste recycling, eco-materials, alternative construction and building materials, supplementary cementing materials and composites materials.

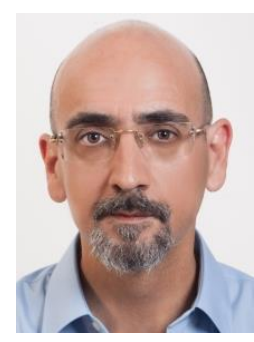

F Pacheco-Torgal is $\mathrm{PhD}$, Principal Investigator at C-TAC Research Centre, University of Minho, Portugal. Holds the Counsellor title of the Portuguese Engineers Association. Author at more of 300 publications. Reviewer and editor for several international journals and books. Grant assessor for several scientific institutions. His major research interests are eco-efficient construction and building materials, mechanical properties, construction and demolition wastes, embodied energy, toxicity of building materials, construction materials biotech based, geopolymers, bio inspired construction materials, alkali-activated cement-based binders (AACB), concrete durability, concrete nanotechnology, industrial waste recycling and civil engineering. 